\title{
Powder for Dental Gen Dosage Form
}

National Cancer Institute

\section{Source}

National Cancer Institute. Powder for Dental Gen Dosage Form. NCI Thesaurus. Code C149817.

Solid preparation consisting of one or more powders intended to be mixed with the specified liquid or gel to obtain a dental gel. 